\title{
Analysis of Attitudes of GenZ Toward Media and Consumption: The Region of Balkans
}

\author{
Nenad Perić, Tatjana Mamula Nikolić, Teodora Delić
}

JEL classification: M31

\section{INTRODUCTION}

Generation Z (GenZ) is made up of almost 2 billion people worldwide. By 2025, they will make up 27\% of the employed population. According to population estimates in Serbia, Croatia and the Republika Srpska, the share of GenZ in the entire population is about 17\% (10 to 25 years of age). In Croatia it is 696,799 GenZ and in Serbia it is 1,271,280 persons aged from ten to twenty-five. Due to migrations that have intensified in the last few years, that percentage varies, and the census in 2021 will show the real situation.

Most researches agree that GenZ, also known as Baby Bloomers, Tweens, Post Millenials and iGeneration, was born after 1994 (Williams \& Page, 2011) and the oldest members are around 26 years old in 2020, so they should be put in 1995-2010 generation. They are also called "Post millenaries", "Digital Natives" (just like previous generation, Gen Y), "Switchers", "Dotcom children", "Netgeneration" (Csobanka, 2016). The youngest members of this generation are now ten years old. Generation $\mathrm{Z}$ (GenZ) is a great opportunity for businesses. They spend about $\$ 200$ billion today, and that will continue to grow as an increasing number of GenZ start working and earning.

GenZ is the first generation that was exposed to the Internet technology from birth. (Yadav \& Rai, 2017) and that was another characteristic of this generation that labeled them as a "Mobile and App Native" Generation. (Persada et al., 2020). GenZ is the first truly digital generation, which through technology, globalization and cultural differences of the 21 st century, had access to trends in fashion, food, Internet entertainment, media and tourism services (Sulin, Whinston, Zhang, 2013).

To better understand GenZ, it is necessary to look carefully at the historical context in which they lived and live. According to the theory of Karl Mannheim, stated by Todor Kuljić (2007), the formation of a certain generation is strongly influenced by events that occur during their growing up, especially during adolescence. These events create a special context that shapes the consciousness, characteristics and behaviors of one generation. Although born in a world facing global challenges such

\begin{abstract}
The paper analyses behaviour of Generation Z (GenZ) in the region of Balkans (Serbia, Croatia and Republika Srpska). It presents the survey that was conducted among young people of age between 12 and 25, during December 2019 and January 2020. Total of 523 persons participated: 309 respondents from Serbia, 102 from Croatia and 112 from Republika Srpska. The analyzed topics were: Generation Z and communication, the role of Internet in life of Generation Z, attitudes of GenZ towards shopping and consumption habits. Besides many similarities of the results between global surveys and this one aiming region of Balkans, some specifics of the region were found and analyzed. The aim of the paper was to present insights that can help researcher (preferably in the field of marketing) to better understand the behavior of GenZ. The conclusion provides an analysis-comparison of similarities and differences of Generation Z in the Balkans comparing to global experiences.
\end{abstract}

Keywords: generation Z, generation $Y$, communication, brand, social networks, consumers 
as recession and climate change, the $\mathrm{VUCA}^{1}$ world, their attitude and activities show that they would like to spend their mature years in a tidy world. Also, this generation shows preferences toward self-employing and entrepreneurship (Seemiller, Meghan, 2016).

Besides the strong exposure to the technology, they also faced global terrorism, school violence, economic uncertainty, mortgage crisis (Williams \& Page, 2011) increased inequality, job insecurity, cloud computing and social media presence (Robinson \& Schänzel, 2019). Mandelbaum (2016) states that GenZ members are always connected, influential, have evolving needs and prefer do-it-yourself ideas and in-person communication, aspire to career goals, have more entrepreneurial style, have respect and are apparently loyal. They are also individualistic, less focused, multi-taskers, tend to have higher expectations (Beall, 2016) and are ready to share their experiences publicly (Slivar et al., 2019).

GenZ tends to be conservative and pragmatic when it comes to finances (Francis \& Hoefel, 2018). Wood (2013) states four trends that characterize GenZ as consumers:

- A focus on innovation.

- An insistence on convenience.

- An underlying desire for security.

- A tendency toward escapism.

According to the research of Pew Center, GenZ is a generation that has acquired attention deficit disorder and developed a great dependence on technology. With characteristic individualism, self-direction and activism, it deals to a large extent with environmental issues, because it is very much aware of the upcoming problems on a global level, such as shortages in water and clean air.

\section{THE ROLE OF THE INTERNET IN LIFE OF GEN Z}

GenZ is constantly online, connected to the Internet, social media, and all kinds of websites, reading, checking, comparing, analyzing, and evaluating options, information and ideas in order to ensure they are making the most out of the whole experience (Dimitriou \& Abou El Gheit, 2019). GenZ utilizes social media and other applications to strengthen the bond between friends and family. Twitter, Instagram, and other social media applications have become

\footnotetext{
${ }^{1}$ VUCA world (volatility, uncertainty, complexity, ambiguity)
}

rather popular in the GenZ. As a result, the increase in technology usage, because GenZ to spend more time with their smartphones, and social media have made online relations developed into a new standard ( $\mathrm{Hu}-$ sein et al., 2017).

They are the first generation to be independent of parents and teachers in gathering information. According to the Trifecta Research (2015) GenZ is connected and conscientious. Technology is important to them but that doesn't mean they want the latest gadget. They still watch TV more than two hours a day but prefer YouTube. Although GenZ is happy and comfortable shopping online, they prefer shopping offline and even $67 \%$ of them would rather shop in stores.

According to the GlobalWebIndex research (2018) top five online activities of GenZ are mostly related to mobile phones, and include the following: visiting/using social network (95\%), using a chat or instant messaging service (92\%), watching a video clip or visiting a video-sharing sites (91\%), visiting or using a search engine (90\%), visiting an online retail sites or stores (79\%). GenZ is becoming more tech-savvy and more privacy-aware. For instance, $60 \%$ say they're concerned about how their personal data is being used by companies and $53 \%$ say they prefer to be anonymous when online. GenZ is $12 \%$ more likely than average to be blocking ads. An overabundance of ads online is the biggest frustration (49\%), with close to a majority also saying they block ads because they are annoying or irrelevant (48\%). Watching TV and video content is the second most important reason for using the Internet amongst GenZ, making them 20\% more likely than general Internet users to hold this view. Of course, social networking and messaging apps represent the most heavily used app categories amongst GenZ. The use of the platforms shows that members of GenZ who are between 16 and 25 use YouTube, WhatsApp and Instagram more, while Snapchat and Tik Tok are more popular among those between 13 and 15 .

Unlike previous generations, GenZ members have always had and will have instant access to a wealth of information on a variety of topics. GenZ quickly shares its opinion with all its virtual friends not only about the experience with brands but also with companies. They usually express themselves very easily about things they don't like through social media (JIang, Fang, Fan, Wang, 2013). There are few things marketers have to have in mind when advertising to GenZ. They want to be communicated with visually and with short, bite-sized content. This is a generation 
that knows how to search and find exactly what they want, so when expectations aren't met, they don't give a second chance. Their limited attention span means brands can never stop working for their business and, since they don't like being sold to, marketers need to find ways to deliver relevant, engaging and immediately beneficial experiences (Trifecta Research, 2015).

Unlike GenY, who are good communicators, they do not prefer face-to-face communication; they will prefer to communicate in writing using text messages via the TikTok, Snapchat, Instagram platforms. For GenZ, information processing time is much shorter, and this is a consequence of the results of the speed with which they have been using the Internet since early childhood. Because they primarily communicate via Instagram and Snapchat, most of GenZ communicate and expresses themselves visually, not verbally, they express themselves through emoticons, images and video clips. They easily select and process virtual data and this fact will really help them in their work later, while for employers it will be a great advantage. On one issue, GenZ continues in the footsteps of GenY: it uses inventive solutions such as "gig economy", circular economy, „shared economy" or economy of sharing, e-learning, m-learning, nanolearning, e-coaching (Mamula \& Ćoso, 2015).

\section{GEN Z BEHAVIOR IN SHOPPING AND CONSUMPTION HABITS}

„GenZ consumers' expectations are higher comparing to previous generations. They want better products and services, more choice and more value; they expect organizations to act in a socially and environmentally responsible manner. Customers are demanding greater customization and are buying more carefully with less risk. The volume and variety of data are increasing with ferocious velocity. Navigating through this digital ocean to get a clear picture of customers is very difficult. Chief Manager Officers, therefore, have to manage more data, understand and engage with more demanding customers, and ensure their employees consistently exemplify organization's values. They have to use tools their children often understand better than they do (Popović-Pantić \& Mamula, 2012).

Mayority of young people are less interested in the identity and history of the brand, and more interested in the specific values of products or services. They are more pragmatic from previous generations and easily switch from one brand to another. GenZ is a global, social, visual and technological generation. BRAND- fog CEO Survey reports that $77 \%$ of respondents are more willing to buy from a company whose mission and values are defined through the participation in social media (Brandfog \& McPherson Strategies, 2018).

According to CommScope Research (CommScope, 2017), 55\% of GenZ prefer to buy clothes online. When it comes to shopping, research shows that $67 \%$ of GenY would visit a website to win a discount coupon, while in GenZ there are $46 \%$. Also, about $79 \%$ of GenY will track ads before buying, which is $20 \%$ more than GenZ. Generation $\mathrm{Z}$ was born in the era of social networks, so it is not surprising that $92 \%$ of members have a profile on a social network.

As a result of the availability of information and following up of media, that generation is looking for something unique in all forms of life. About $58 \%$ of people over the age of 35 in the world agree with the statement that today's children have much more in common with their peers around the world than with adults from their environment. (Beall, 2016). In addition, it is noticed environmental awareness of young people regarding travel (Skift Research, 2019), in attitudes towards fashion (Amed et al., 2019) and nutrition.

\section{GEN Z BEHAVIOR IN THE REGION OF BALKANS: SERBIA, CROATIA AND REPUBLIKA SRPSKA}

\section{Methodology}

In December 2019 and January 2020, a research was conducted among young people between 12 and 25, in which a total of 523 people participated: 309 respondents from Serbia, 102 from Croatia and 112 from Republika Srpska. The responses obtained in the surveyed countries differ slightly from each other, and generally do not deviate much from GenZ research in the world. Due to the wide range of years, surveyed members of GenZ included primary school students, high school students, students as well as employees. It should be noted that most of this generation depends on the budget of their parents and that the display of their consumer role is currently limited.

Empirical, quantitative, research was conducted online using the method of questioning via Google Forms, during December 2019 and January 2020. The sample is representative for online population in all three countries. The questionnaire was tested face to face in each country before it was launched online. Several universities and secondary schools in differ- 


\section{CHART 1: Age and Gender of respondents}

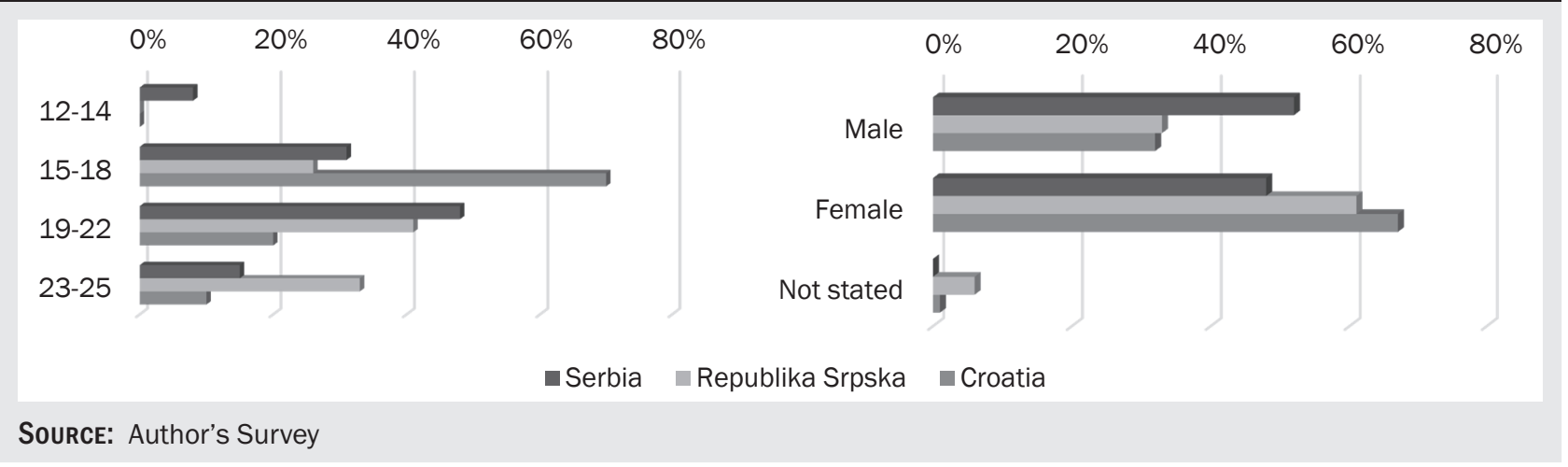

CHART 2: Occupation of respondents

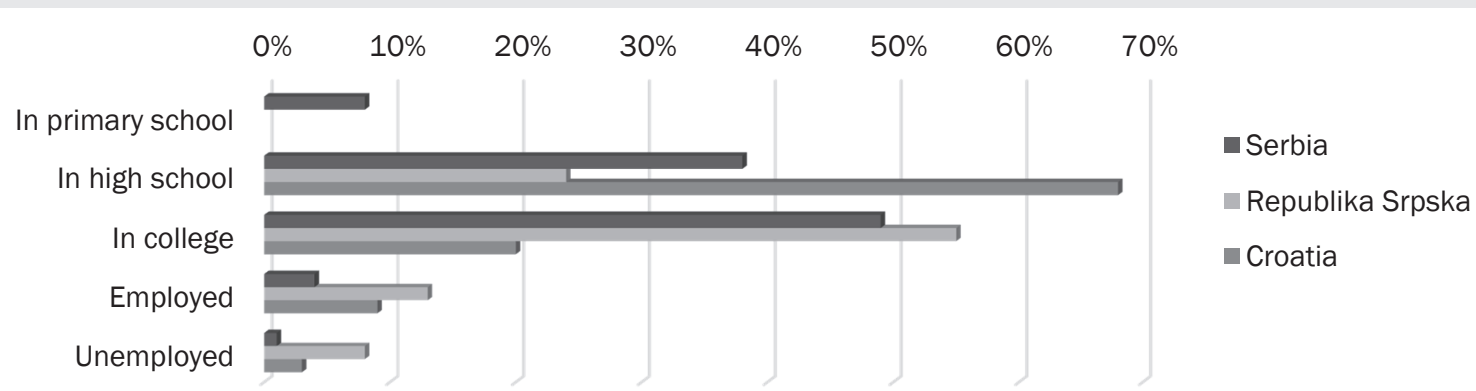

SOURCE: Author's Survey

ent cities promoted the link to the survey. The questionnaire was localized and prepared in three different languages.

The aim of the survey is better understanding of:

- ways of communication of young people with each other,

- relations of young people with modern media and

- Consumer roles of young people.

SPSS software was used for data processing and interpretation of the obtained results, and quantitative statistical methods were used for analysis.

\section{RESULTS}

The survey showed the results that follow.

\section{Social communication}

The vast majority of respondents has a need to be up to date with current events. In order to be able to achieve this on a daily basis, respondents rely on as many sources of information as possible. Social net- works and Internet surfing are in a convincing lead. About $80 \%$ of respondents of all three samples prefer to read in electronic form rather than in printed form. Their attachment to the phone, tablet and computer has led GenZ to the point where they expect easily available information on them.

When it comes to social networks that they use in everyday, Instagram and YouTube have a convincing lead. As many as $45.7 \%$ of respondents from Serbia, of age between 12 and 17 (144 respondents) chose the Snapchat platform, and only $10 \%$ of them chose Facebook. While the popularity of Facebook is declining as respondents are younger, the popularity of Snapchat and TikTok is growing. As far as mutual communication with friends is concerned, GenZ has a much greater propensity for calls with $63.4 \%$, as well as for live communication with $45.6 \%$, unlike GenY who are most prone to chatting.

In Serbia and Croatia, the ratio is very similar in terms of the following platforms:
Messenger (41\%)
WhatsApp (58\%)
Instagram $(73 \%)$
Viber (38\%). 
Chart 3. Ways of everyday informing - Serbia

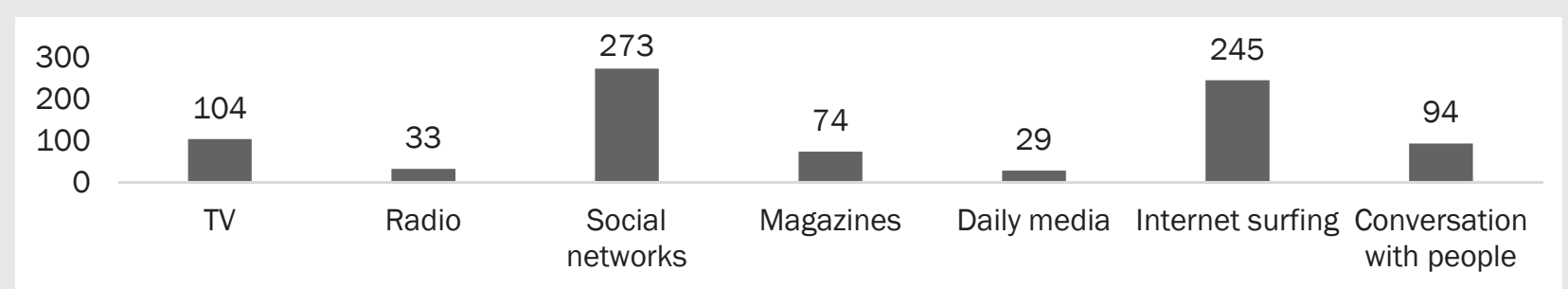

SOURCE: Author's Survey

CHART 4. Preferred networks - Serbia

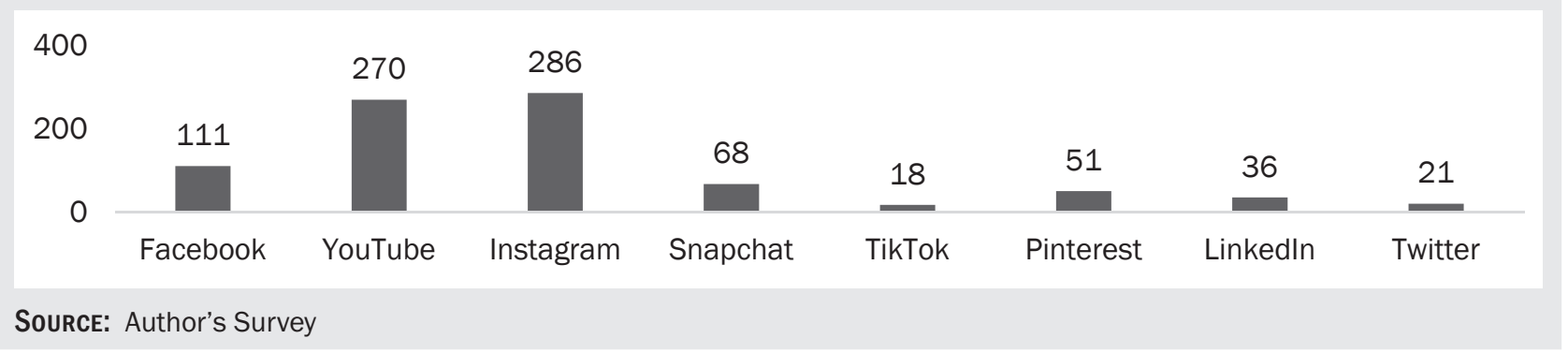

On the other hand, in Republika Srpska, the use of Viber (55.8\%) and Messenger (60\%) is more popular, while Instagram was used less with $54 \%$. What is important for communication is that no form of communication channels is strange to them and that, depending on the trend, any visual form of communication can be used at the right time as the best way to convey a message. Technology has enabled inclusivity to GenZ, but has also created negative consequences that can be very dangerous for the psyche of young people.

In Serbia, $69 \%$ of respondents said they could not function without a mobile phone, in Republika Srpska $77.9 \%$, and in Croatia as much as $93.9 \%$.

\section{Attitude towards traditional media}

When it comes to any form of media, in order to convey a message, it is very important that there is some kind of trust between the one who sends the message and the one who receives it. The overcrowding of information has led to a situation where contradictory news reaches young people and, due to a large amount of misinformation, they stop trusting some communication channels.

Based on the research, it is shown that young people in Serbia believe that television provides the most accurate news with $42.4 \%$ of votes, while other media received about $10 \%$ of votes (radio and daily press). On the other hand, in Croatia, TV received as much as $75.4 \%$ of the vote, radio $33.8 \%$, the daily press $30 \%$ and social networks $15 \%$. As for radio, its popularity in the region is slightly lower than in the world. It is often listened to by $48 \%$ of respondents while about $15 \%$ never listen to it.

However, television ratings are constantly declining in terms of the percentage of viewers among the younger generations. On average, about $15 \%$ of respondents said they never watch TV. The highest TV rating is in Serbia, where $64.8 \%$ of respondents chose to watch it often, while in Croatia it is the lowest with $16.7 \%$. In Croatia, as many as $28.8 \%$ never watch TV, while that percentage in Serbia is around 5\%. Most respondents watch TV "from time to time“ in the following percentages: Republika Srpska 31\%, Croatia $28.8 \%$, Serbia $21.2 \%$. As for radio, its popularity in the region is slightly lower than in the world. It is often listened to by $48 \%$ of respondents while about $15 \%$ never listen to it.

\section{GenZ in the role of consumer}

About $50 \%$ of GenZ underage members from Serbia said they preferred advertising as a video, and only $25 \%$ as a photo. They had the option of more choices, so they opted also for sharing free samples with $38.2 \%$, 
CHART 5. Type of purchase

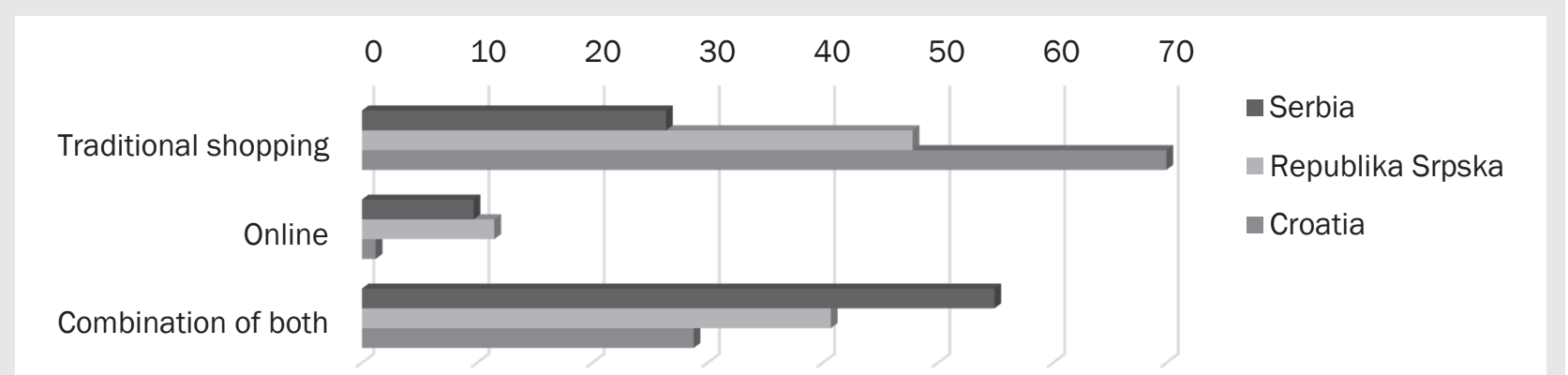

SOURCE: Author's Survey

activity sponsorships with $18.1 \%$, and commercials in a form of sound won only $2.8 \%$.

Short videos are an increasingly common form of marketing communication due to the narrowed focus of this generation, and other aspects range from video billboards on the street to short videos on phones. However, when asked how all forms of advertising affect them, most young people answered that they ignore them, while $16 \%$ said that they are repulsive. A total of $30 \%$ of respondents said that advertisements encourage in them the desire to buy. Such answers have nothing to do with trust in advertisements, because $83 \%$ of respondents from all countries do not believe in advertisements they see on TV, billboards and social networks, increasingly prefer co-creation and to actively participate in brand preparation and advocacy.

Since advertisements have become almost fused with most free applications on the phone, $58.3 \%$ of the youngest GenZ from Serbia have installed an application that was advertised in another application. This mostly happens with games on the phone that advertise other games. Although they are directed in this way, about $85 \%$ of young people say that they are very bothered by advertisements in applications.

Regarding the purchase and consumer role of this generation, local GenZ was asked questions related to the way they purchase. The great availability of products over the Internet and various technical devices makes it today easy to shop online. However, in Croatia almost $70 \%$ of young people prefer to go to stores, in Republika Srpska 47.8\%, and in Serbia 26.4\%. Traditional and online shopping are most often combined in Serbia with 54.9\%, in Republika Srpska with 40.7\%, and the least in Croatia with $28.8 \%$.

We can observe this behavior from the angle that they still do not have their own financial resources if we compare it with the behavior of GenY in Serbia, where almost half of them do not purchase online. (Mamula et al, 2020). In order to decide on a purchase, in Croatia and Republika Srpska, about 50\% of respondents make their own decision on the spot, and about $10 \%$ consult with the seller. In Serbia, that number is lower, where $37.8 \%$ make decisions independently, and $30 \%$ read reviews on blogs and $15.2 \%$ read reviews on the manufacturer's website. It is interesting that in Republika Srpska a smaller percentage is informed through blogs with $21.2 \%$, and through influencers and reviews on the Internet below $10 \%$. In Croatia, reviews from the manufacturer's website (21\%) and reviews from blogs (15\%) are looked for.

One can also see their caution and attitude towards money. It is considered that one of the main wishes of this generation is to be financially stable in the future, and thus they have a responsible attitude towards spending money. Even now, as adolescents, they are aware and careful with the use of money. $52 \%$ of respondents stated that they usually plan $60 \%$ of purchases, and only $8 \%$ stated that they use money completely impulsively.

\section{CONCLUSION}

GenZ in the region of Balkans is similar to its peers in the world. The connection of this generation on a global level leads to the fact that their general interests overlap a lot, noticeably more than of the older generations. The findings are mostly in line with Trifecta Research (2015), GlobalWebIndex research (2018) and others quoted in Introduction. Nevertheless, we founded some interesting differences.

The main source for searching information for the GenZ is online media channels. In this region, the most popular social networks among this gen- 
eration are Instagram, then YouTube and then Facebook. Snapchat is in the fourth place, far behind the mentioned ones. But in the Taking Stock with Teens survey conducted in America among GenZ, the results are different. Snapchat is in a convincing lead with $45 \%$ of votes, while Instagram is in second place with $26 \%$, and the Facebook platform with only 5\% of votes. In addition, a huge percentage of GenZ, as many as $71 \%$ use Snapchat on a daily basis. We can conclude that the shift in popularity from Facebook to Instagram was due to the need for young people to express themselves visually, which coincides with the insight of Van Dijk \& Poell (2013). And the narrowed focus and shortened range of attention of young people has led to the popularity of Snapchat, as well as of TikTok, where pictures and videos are short-lived. To counter these apps, Instagram has introduced the Story option, so its popularity is still huge. However, in the region, the popularity of Snapchat and TikTok networks is bigger with younger members of GenZ, and a further increase in the popularity of these social networks can be expected.

As technological and digital natives, GenZ is radically inclusive worldwide. They are constantly moving between communities that promote their views through the high level of mobilization that technology allows. Also, GenZ is tuned for voluntarism and activism, it cares about improving the world and actively chooses brands that work to make the world a better place. GenY started and GenZ intensified its relationship with brands that build as much on the brand's appeal as on the brand's impact on the environment (Argintaru, 2020). Social responsibility of brands and their purpose has a big impact on whether GenZ will show them loyalty or not. (Porter Noveli Cone Research, 2019). This is followed by the proactive attitude of members of this generation buy in stores (offline) worldwide and in the region of Balkans also, although the results vary much from country to conutry $(70 \%$ in Croatia vs 26.4 in Serbia, Republika Srpska is in the middle with 47.8). This result in less extreme when we take a look on combination of traditional and online shopping, which is most often combined in Serbia (54.9\%), and the least in Croatia with $28.8 \%$, where Republika Srpska ia agin in the middle with $40.7 \%$.

GenZ neither trust nor don't trust the information found, seen or heard on/in the media, so the information presented in the ads about the destination has to be honest, accurate, testable, relevant and presented in the language that GenZ understands. GenZ does not like the interruption, so marketers and advertisers have to focus on creating the ads that will not make a negative impact which will result with changing the radio station or channel. As the GenZ largely notices ads on online media as well, but they are bothered by those ads, innovation in design and using nontraditional placements and forms of ads is desirable. These are also the characteristic of members of Generation $\mathrm{Z}$ in the region of Balkans. So, it is essential to communicate with the GenZ at the time when they want and where they want. They will notice innovation, social awareness and quality stories. The storytelling should also be used as a method to gain awareness and trust. Authenticity and thoughtful interaction are important for GenZ.

That's why companies need to focus on communicating with this generation on a personal level. Since GenZ members spend most of their time online watching videos on their mobile devices, brands must have a presence on social networks given the rapid changes in the popularity of social networks, because the networks primarily used by this generation originated in the previous decade. In addition, partnership with micro influencers is necessary, because they have more influence on GenZ than well known personalities.

However, when we talk about trust in a certain type of media, GenZ in the region of Balkans is turned to television. Trust in television probably arose from the idea that information passed certain checks and approvals on this medium before it reached them, although for the older generations it would be the printed media first. But the digital generation does not consume printed media and therefore it is logical that it is turned to television on this issue, because for them that media is a traditional one. Members of this generation decide to buy on the basis of various information: those obtained at the point of sale, through blogs and influencers. Regardless of the noticeable differences between the samples, this is a significant difference compared to the previous generation that marketers should pay attention to. A large percentage of them try to make purchasing decisions according to plan and not to be influenced by advertisements. They tend to make their own decisions, but are increasingly being consulted with comments on the Internet through reviews on sites, blogs and influencer profiles. Also, the results show that young people in the region like advertising in the form of video and photoCharty.

One should also keep in mind their caution towards money. The responsibility that this generation has towards spending money is connected with one of the main desires of GenZ, and that is financial stability. 
This is followed by the fact that a very small percentage of this generation buys impulsively-in this survey only $8 \%$ ), while $52 \%$ of respondents stated that they usually plan $60 \%$ of purchases. This sales and marketing teams in a position to develop sales strategies with a high degree of adjustment.

Acknowledgment: We thank the assistant professor Mirjana Milovanović, PhD from Banja Luka, MA Ivana Radić from Zagreb and the Student Parliament Metropolitan University, student Sanja Šunjevarić from Belgrade in conducting surveys.

\section{References}

1. Amed, I., Berg, A., Balchandani, A., Beltrami, M., Berg, A. Hedrich, S., Felix, R. (2019). The State of Fashion. McKinsey and Company.

2. Argintaru, D. (2020) (2020) Through COVID-19, Leading Brands Have Found Their Purpose, Contributing Writer, CMO by Adobe https://cmo.adobe.com/articles/2020/5/throughcovid-19--leading-brands-have-found-their-purposehtml\#gs.9bnf3v

3. Beall, G. (2016). 8 Key Differences between Gen $\mathrm{Z}$ and Millennials. Huffington Post. Retrieved from https://www.huffpost.com/entry/8-key-differencesbetween_b_12814200

4. BRANDfog \& McPherson Strategies (2018). CEOs Speaking Out. Retrieved from https://brandfog.com/ survey/2018_ceo_survey.pdf

5. CommScope Research (2017). Retrieved from https://www.commscope.com/press-releases/2017/ commscope-research-on-gen-z-tech-intimatesreveals-an-always-on-mindset/

6. Csobanka, Z. (2016). The Z Generation, Loránd Eötvös University, Faculty of Pedagogy and Psychology, Budapest, Hungary; Acta Technologica Dubnicae volume 6, 2016, issue 2.

7. Dimitriou, C.K., AbouElgheit, E. (2019). Understanding generation Z's social decision-making in travel, Tourism and Hospitality Management, Vol. 25, No. 2, 311-334.

8. Francis, T., Hoefel, F., (2018). True Gen': Generation $\mathrm{Z}$ and its implications for companies, McKinsey and Company;

9. Husein, K., Wiweka, K., Kurniawati, R., Adnyana, I.N. (2017). The profile and behavior of „SMART TOURIST' (Generation Z) in travel decision making. 4th World Research Summit for Tourism and Hospitality, 8-11.12.2017, Orlando, USA.

10. Kuljić, T. (2007). „Problem of Generations: Origins, Content and Continuing Relevance of Karl Mannheim's Article“, Journal of Sociology, Social Psychology \& Social Anthropology, 2007, 49:3.

11. Mamula T, Popovic Pantic S, Muller I. (2020) The Impact of ICT and Digitalization on Consumer Purchase Behaviour of Millennials as emerging
Economic and Social Force-the Case of Serbia, Society and Technology, Opportunities and Challenges, ICT and social development, Society and Technology. London: Routledge, https://doi. org/10.4324/9780429278945

12. Mamula, T., Ćoso, D. (2015). Millennials' way of e-learning and communication in digital era, The Sixth International Conference on e-Learning (eLearning-2015), 22-23.9.2015, Belgrade, Serbia.

13. Mandelbaum, A. (2016). What Should Your Hotel Know About Generation Z?. Retrieved from https:// lodgingmagazine.com/what-should-your-hotel-knowabout-generation-z/

14. Persada, S.F., Ivanovski, J., Miraja, B.A., Nadlifatin, R., Mufidah, I., Chin, J., Perwira Redi, A.A.N. (2020). Investigating Generation Z' Intention to Use Learners' Generated Content for Learning Activity: A Theory of Planned Behavior Approach, International Journal of Emerging Technologies in Learning, Vol 15(4),179-194.

15. Pew Research Center: Defining generations: Where Millennials end and Generation $\mathrm{Z}$ begins, Retrieved from http://www.pewresearch.org/ fact-tank/2019/01/17/where-millennials-end-andgeneration-z-begins/

16. Popović-Pantić, S., Mamula, T. (2012). The role of social media in smes sector in the new transition's economies, $19^{\text {th }}$ Conference with International Participation: Technology, Culture and Development, Tivat, September 2012.

17. Porter Novelli Cone Research (2019) Undivided, GenZ purpose study, https://www.fusemarketing. com/thought-leadership/purpose-driven-brandssustainability-gen-z/

18. Robinson, V. M., Schänzel, H.A. (2019). A tourism inflex: Generation $\mathrm{Z}$ travel experiences, Journal of Tourism Futures, Vol 5(2), 127-141.

19. RZS Srbije i DZS Hrvatske (2019).

20. Seemiller C., Meghan G. (2016). Generation Z Goes to College. USA: Jossey-Bass.

21. Skift (2019), Skift's 2019 Millennial and Gen Z Traveler Survey, Retrieved from https://research.skift. com/wp-content/uploads/2019/08/MillennialGenZ_ Final.8.12.pdf 
22. Slivar, I., Aleric, D., Dolenec, S. (2019). Leisure travel behavior of generation $\mathrm{Y} \& \mathrm{Z}$ at the destination and post-purchase, E-Journal of Tourism Vol 6(2), 147159.

23. Sulin, B., Whinston, A., Zhang, H., (2003). Building trust in online auction markets through an economic incentive mechanism, Decision Support Systems, 35, $273-286$.

24. Trifecta Research (2015). Generation Z Media Consumption Habit, Retrieved from http:// trifectaresearch.com/wp-content/uploads/2015/09/ Generation-Z-Sample-Trifecta-Research-Deliverable. pdf

25. Van Dijck, J., Poell, T. (2013). Understanding Social Media Logic. Media and Communication, 1(1) ,2-14. DOI.org/10.17645/mac.v1i1.70.

26. Whistle Sports (2019). „From Nerdy to Norm: Gen Z Connects Via Gaming. Retrieved from https://www. hrreview.co.uk/hr-news/gen-z-proclaim-themselvesas-the-hardest-working-workforce/11666

27. Williams, K.C., Page, R.A. (2011). Marketing to the Generations, Journal of Behavioral Studies in Business, Vol 3 (1), 1-18.

28. Wood, S. (2013). Generation Z as consumers: Trends and innovation. Institute for Emerging Issues: NC State University, https://iei.ncsu.edu/wp-content/uploads/2013/01/ GenZConsumers.pdf

29. Yadav, G. P., Rai, J. (2017). The Generation Z and their Social Media Usage: A Review and a Research Outline, Global Journal of Enterprise Information System, Vol 9(2), 110-116.

30 Jiang, Z., Fang, S., Fan, Z., Wang, D. (2013). Selecting optimal selling format of a product in $\mathrm{B} 2 \mathrm{C}$ online auctions with boundedly rational customers", European Journal of Operational Research 226, 2013, 139-153.

\section{Apstrakt:}

\section{Analiza stavova GenZ prema medijima i potrošnji: region Balkana}

Nenad Perić, Tatjana Mamula Nikolić, Teodora Delić

U radu se analizira ponašanje generacije Z (GenZ) na Balkanu (Srbija, Hrvatska i Republika Srpska). Predstavljeni su rezultati istraživanja koje je sprovedeno među mladima od 12 do 25 godina tokom decembra 2019. i januara 2020. Ukupno je učestvovalo 523 ispitanika: 309 ispitanika iz Srbije, 102 iz Hrvatske i 112 iz Republike Srpske. Analizirane teme su bile: Generacija Z i komunikacija, uloga interneta $\mathrm{u}$ životu generacije Z, navike u kupovine i potrošnji GenZ. Pored mnogih sličnosti rezultata između globalnih istraži- vanja i ciljanog regiona Balkana, pronađene su i analizirane i neke specifičnosti regiona. Cilj rada je bio da predstavi uvide koji mogu da budu od pomoći istraživačima (prevashodno marketarima) da bolje razumeju ponašanje GenZ. Zaključak daje analizu-poređenje sličnosti i razlika o generaciji $\mathrm{Z}$ na svetskom i nivou Balkana.

Ključne reči: generacija $Z$, generacija $Y$, komunikacija, brend, društvene mreže, potrošači

\section{Kontakt:}

Nenad Perić, nenad.peric@metropolitan.ac.rs, Tatjana Mamula Nikolić, tatjana.mamula@metropolitan.ac.rs, Teodora Delić, teodora.delić@gmail.com, Metropolitan University Belgrade, Faculty for Management, Tadeuša Košćuška 63, 11000 Beograd 